\title{
Type of Community Participation in the Implementation of the Village Family Planning Program (Case Study in Layang-Layang Family Planning Village as Pilot Project in Palembang)
}

\author{
Dwi Mirani* \\ Faculty of Sosial Science and Political Science \\ Sriwijaya University \\ Palembang, Indonesia \\ miranidwi@gmail.com \\ Martina Martina \\ Faculty of Sosial Science and Political Science \\ Sriwijaya University \\ Palembang, Indonesia
}

\author{
Zailani S \\ Faculty of Sosial Science and Political Science \\ Sriwijaya University \\ Palembang, Indonesia \\ Marpaung Marpaung \\ Faculty of Sosial Science and Political Science \\ Sriwijaya University \\ Palembang, Indonesia
}

\begin{abstract}
The Village Family Planning (Kampung KB) program is a national program from the government aimed at solving the problems of population density and also forming a prosperous family free from poverty, especially slums, suburbs, and fishing villages. In Palembang, $16 \mathrm{~KB}$ Villages have been formed out of 18 existing sub-districts. Among the existing KB villages, the KB Layang-layang village was declared as a pilot village due to its activeness in implementing the program compared to other $\mathrm{KB}$ Villages. This study aims to describe the type of community participation and the factors that influence the success of the implementation of the KB villages program in the Layang-layang $\mathrm{KB}$ village. The method used in this research is qualitative method with a descriptive approach. Data collection techniques using interviews, observation, and documentation to the village cadre and community members. The results showed the type of community participation in the KB Layang-layang village was a functional type of participation. Realized with the formation of a working group, agreed on rules and community independence. Supporting factors for the success of this program include community understanding, active participation of cadres, continuous socialization, the role of community leaders and stakeholder support. In addition, there are several inhibiting factors, including limited funding, lack of coordination across the sectors, community involvement is not yet comprehensive, and lack of guidance from various fields. Finally, community independence and assistance from various parties are still needed for the success of the program to realize the goal of the program.
\end{abstract}

Keywords--family planning, KB village, community participation.

\section{INTRODUCTION}

The United Nations (UN), on 25 September 2015 at the UN headquarters, has endorsed the agenda of sustainable development goals or referred the SDGs as a global development agreement. SDG contains 17 goals and 169 targets are global action plans for the next 15 years (effective from 2016 to 2030), to reduce poverty, reduce division and protect the environment. SDG applies to all countries (making it universal) so that all countries without having to have morals to achieve goals and target SDGs [1]. As a manifestation of the government's political commitment to implement SDGs, President Jokowi has approved Presidential Regulation (Perpres) No. 59 of 2017 concerning Implementation of Achieving Sustainable Development Goals. This Perpres is also a commitment to be implemented and agreed upon by the SDGs which is carried out in a participatory manner involving all parties in the community, government, private sector, and international parties.

In line with the SDGs, President Jokowi's government through his Nawacita issued policies that bridge the realization of the SDGs' objectives. Then, the policy is downgraded into regional development programs implemented by local governments. In the era of regional autonomy and development efforts, the local government did a lot of innovation. The regional development innovation program aims to improve the services received by the community in an effort to improve the welfare of the people in the regions, especially in areas that are less affordable.

Regional innovation development is carried out in two regional regions, namely for the rural and district city areas. In the rural area, it is called the village innovation program (desa Inovasi). In the district city areas, it is called the village innovation program (kampung inovasi). The village innovation program in the rural/district city areas gave rise to villages with unique themes and names designed on the basis of local wisdom and the potential of each region. These programs are also used as a means of resolving the problem of affordability of access to services to the community. In urban villages, innovation becomes a solution for several important problems faced by the city government including environmental, health, population, slum areas, sanitation, water supply, etc. In line with the SDGs agenda, namely the eleventh sustainable development goal, which is to build cities and settlements that are inclusive, safe, durable and sustainable. The city government must be able to create a city that is comfortable 
for citizens and to think of the sustainability of the development of an urban area. Therefore, innovation villages were created with their respective themes and uniqueness, such as the rainbow village, environmentally friendly village, legal awareness village, family planning village, tourism village, etc [2]. This research will raise the issue of problems faced by the city government in an effort to overcome urban problems that arise as a result of globalization. The issue raised is population issues.

The issue of the population was raised in this study because cities have a large appeal so that the population is very dense. Population density will make it difficult to provide access to services for the city community, besides also causing negative impacts in the form of the emergence of slums and low health levels due to limited facilities and personnel medical. These problems must be quickly resolved by the regional government so that the welfare of the community can be guaranteed.

On the other hand, the largest population in South Sumatra is in the city of Palembang. Based on data from the Central Statistics Agency (BPS) of South Sumatra Province in 2018 the population of Palembang city is quite high, amount of $1,651,857$ people, in the last five years (20132018), a significant increase in the number of 115,921 people or around $+7,5 \%$ of $1,535,936$ people (2013). Followed by Banyuasin in second place amount of 846,269 people and Ogan Komring Ilir in third place betting 821,528 people. The considerable distance between the city of Palembang and other districts indicate the interest of the community to live in the city of Palembang is quite high. The large number of residents in the city of Palembang can occur because of two reasons; first, discussing urbanization of populations originating from the province of South Sumatra and from outside the province. Second, the increase in population due to the number of births due to non-optimal family planning programs or unreachable programs for the people of Palembang. The dense population will cause a lot of debate, restore slums, distribute clean water, traffic jams, crime, etc.

Various attempts to overcome these important issues including involving the active role of the community in planning and implementing programs related to population issues in the city of Palembang. The government of Palembang city in dealing with issues that exist in urban areas, specifically population, seeks to embrace the community through the village family planning program (Kampung KB).

The Village Family Planning (KB) program is a program declared by the government in an effort to overcome population problems, in areas that are difficult to reach by the government, especially for slums, remote areas, and fishermen. The purpose of $\mathrm{KB}$ villages is to improve the quality of life of people at the village level or equivalent through the KKBPK program and the development of other sectors in order to create quality small families. In 2017 it is targeted to have one KB Village in every one sub-district throughout the region of Indonesia. In other words, there will be around $7166 \mathrm{~KB}$ villages throughout Indonesia. For the implementation, the $\mathrm{KB}$ village requires the involvement of all sectors in the community. The program has been implemented by the Palembang City government and continues to develop performance areas. As proof of the seriousness of the Palembang city government in an effort to overcome population problems. In the city of Palembang, there are $16 \mathrm{~KB}$ villages located in each sub-district. The success of these programs is highly dependent on the participation of the community. Of the many existing $\mathrm{KB}$ villages, the Layang-layang $\mathrm{KB}$ villages received serious attention from the government and the private sector. In addition, the Layang-layang $\mathrm{kb}$ village has received several awards for the best $\mathrm{KB}$ village in the city and the best $\mathrm{KB}$ cadre at the national level.

According to the Head of the Representative Office for Population and Family Planning (BKKBN) of the South Sumatra Province (South Sumatra) Waspi, Wednesday $(13 / 2 / 19)$, this program was only given to KB villages who were willing to move.

" Actually, all the attention, it's just that private and government attention, only to the $\mathrm{KB}$ village who want to move, if the people do not want to move, who wants to help, then later what is helped," he arrived. "He further added" Like today, the KB village is good and quite a lot of private parties are helping. That's what we really want, that this $\mathrm{KB}$ village is formed from the community, by the community, and for the community ". (https://www.swarnanews.co.id/2019/02/13/perhatianserius-palembang-miliki-16-kampung-kb/)

Based on this explanation it can be said that the Family Planning Village Program is dependent on community participation and government attention will only be given to villages where the community has a great concern to move forward in the village. In addition, a synergy between the government and the private sector is needed. Seeing the success of the innovation KB village programs implemented by the Palembang City government, it is inseparable from the important role of community participation, it can be assumed that the success of the village family Planning program will be greatly influenced by community participation.

\section{LITERATURE REVIEW}

\section{A. The concept of community participation}

In a country, there are two development implementers, the executor (government) and the target group (community). Development can proceed if there is synergy between the government and the community. However, by applying the concept of decentralization in Indonesia, the role of the community is no longer just a development target group but can also be an implementer of development programs. This role called community participation.

Community participation at the regional level in the Implementation of Regional Government-regulated in Government Regulation Number 45 of 2017 concerning community participation, which states what is called community participation is the role of the community to channel their aspirations, thoughts, and interests in involving local government.

Community Participation in the administration of the relevant regional government, among others as a place for the community both individuals, community groups, and community Organizations in their needs and interests 
requires the process of making local policies more responsive to the needs and interests of the community. Community participation is also important in realizing community care and support for development in the region. Community participation is considered important in a community development program that is more understanding of their own problems, interests or needs. In development activities, community participation is an expression of awareness and concern and responsibility of the community towards the importance of development aimed at improving their quality of life [3].

Community participation is the process of identifying problems and potential that exist in the community, selection and decision making about alternative solutions to deal with problems, implementing efforts to overcome problems, and community involvement in the process of evaluating changes that occur [4]. The manifestation of the desire to develop democracy through a decentralized process that is pursued planning that comes from the bottom (bottom-up) with community participation in the planning and development process [5]. On the other side, monitoring and evaluation of development programs or projects are needed, this is because there are objectives to be achieved and constraints that must be faced. For this reason, community participation is needed to gather information related to the development of activities and the growing of program or project implementers in the development process [3]

Community participation based on individual position in the community is divided into vertical participation and horizontal participation. Vertical participation happens by the community involved or taking part in a program of another party, in which the community is domiciled/subordinate, follower or client. While in horizontal participation, the community has an initiative where each member or community group speaks horizontally with one another. This kind of participation is the beginning of a society that develops independently.

Therefore, it can be said the concept of community participation is an effort to realize the active participation of the community in planning, implementing, supervising and evaluating in every development program aimed at ensuring the success of governance in order to achieve development goals both at the center and in the regions.

\section{B. The type of community participation}

Type of community participation, we can also call the level of participation carried out by the community. The type of participation describes the degree of community involvement in the participation process based on the amount of power that the community has to be involved in the decision-making process [6]. Community participation identifies 7 (seven) types based on their characteristics [3].

TABLE I. TYPOLOGY OF PARTICIPATION

\begin{tabular}{|c|c|c|c|}
\hline No & Typology & & Characteristics \\
\hline 1 & Passive/manipulative participation & & $\begin{array}{l}\text { Communities participate by being notified of what is happening or have happened } \\
\text { Unilateral announcements by project management or implementers without regard to } \\
\text { community responses; } \\
\text { The information exchanged is limited to professionals outside the target group. }\end{array}$ \\
\hline 2 & Participation by providing information & $\begin{array}{l}\text { (a) } \\
\text { (b) } \\
\text { (c) }\end{array}$ & $\begin{array}{l}\text { The community participates by answering research questions such as in questionnaires or } \\
\text { the like, } \\
\text { The public does not have the opportunity to be involved and influence the settlement } \\
\text { process; } \\
\text { The accuracy of the research results is not discussed with the community. }\end{array}$ \\
\hline 3 & Consultation participation & $\begin{array}{l}\text { (a) } \\
\text { (b) } \\
\text { (c) } \\
\text { (d) }\end{array}$ & $\begin{array}{l}\text { The community participates in consultation, } \\
\text { Outsiders listen and build their own views to then define the problem and its solution, by } \\
\text { modifying the community's responses; } \\
\text { There are no opportunities for joint decision-makers; } \\
\text { Professionals are not obliged to submit community views (as input) for further action. }\end{array}$ \\
\hline 4 & Participation for material incentives & & $\begin{array}{l}\text { The community participates by providing resources such as labor, for food, wages, } \\
\text { compensation, etc. } \\
\text { The community is not involved in the experiment or learning process; } \\
\text { The community has no contribution to continue the activities carried out when the } \\
\text { incentives provided/received are exhausted. }\end{array}$ \\
\hline 5 & Functional participation & $\begin{array}{l}\text { (a) } \\
\text { (b) } \\
\text { (c) }\end{array}$ & $\begin{array}{l}\text { The community participates by forming groups to achieve objectives related to the project, } \\
\text { Formation of the group (usually) after the main decisions have been agreed; } \\
\text { Initially, this community group was dependent on outsiders (facilitators, etc.) but in time } \\
\text { was able to be independent. }\end{array}$ \\
\hline 6 & Interactive participation & & $\begin{array}{l}\text { The community participates in the joint analysis that leads to activity planning and the } \\
\text { formation of new social institutions or the strengthening of existing institutions, } \\
\text { This participation tends to involve interdisciplinary methods that look for diversity of } \\
\text { perspectives in structured and systematic learning processes; } \\
\text { Community groups have a control role in their decisions, so they have a share in all }\end{array}$ \\
\hline 7 & Self-mobilization & & $\begin{array}{l}\text { Communities participate by taking initiatives freely (not influenced/pressured by outsiders) } \\
\text { to change their systems or values, } \\
\text { Communities develop contacts with other institutions to get technical assistance and } \\
\text { resources required; } \\
\text { The community holds control over the use of available resources. }\end{array}$ \\
\hline
\end{tabular}




\section{METHODS}

This study uses a qualitative method with a descriptive approach. The focus of research on the type of community participation and the factors that influence success in the KB villages program. The research located in the Layanglayang KB village of Palembang City.

Data collection techniques used in this study were observation, interviews and also documentation. The interview was conducted with the village cadre and community members. Observations were made by looking at the activities and behavior of the community in the Layang-layang KB village. Data documentation is needed to check the truth of the information that has been said by the informant in the interview.

To strengthen data analysis, triangulation of data is used by cross-checking answers to sources of documents and interviews with relevant parties [7]. The data analysis technique is based on the Interactive Model of Analysis [8]. The data analysis activities are data reduction, data display and conclusion drawing/verification [7]. The data analysis technique used to analyze the answers and activities of people to determine the type of community participation and the suggestion factor of success in this program.

\section{RESULTS}

\section{A. The type of community participation of the Layang- layang $K B$ village}

The results showed the type of community participation in the KB Layang-layang village was a functional type of participation. Realized with the formation of a working group, agreed on rules and community independence. Working groups (Pokja) were formed and approved using the camat's decree in each sub-district. For the Layanglayang KB village, a Pokja decision letter was made by the Ilir Barat II District Head. everyone in the working group has their respective duties in accordance with the activities to be carried out in the KB village program. The activities carried out by the Layang-layang $\mathrm{KB}$ village include Toddler Family Development, Teen Family Development, Elderly Community Development, PIK-R dan UPPKS. In carrying out their duties, cadres are given assistance by KB counselors who are appointed by the Office of Population Control and Family Planning.

In the Implementation of its activities, Layang-layang $\mathrm{KB}$ village represents that $\mathrm{KB}$ family members are very enthusiastic about various activities that are held. it's just that in cleaning activities, public awareness is still lacking to protect the environment. KB villages have 286 households where $85 \%$ of the community's economy is lower middle class, and on average each family has more than 3 children. Participation in family planning activities is dominated by $75 \%$ of the adult population and $25 \%$ of teenagers.

The independence of the Layang-layang $\mathrm{KB}$ village has been seen from the activities every week. That start involving other parties, cooperation, agreements with private companies such as Medco energy company and Muhamadiyah universities Palembang. The KB village management carries out a memorandum of understanding with the university to assist activities in the $\mathrm{KB}$ village.
Ongoing activities have participated in every citizen voluntarily, but some people are still forced and persuaded to join this activity. KB village cadres have started selling products that are produced from coaching activities carried out by various parties. For example, songket souvenirs and ginger drink. As a kite producer, Layang-layang $\mathrm{KB}$ village sales product has increased since this village was declared a pilot KB village because it was reported by outside mass media that people knew that the village was a kite center. in addition, the level of health and welfare of the Kampung KB community has improved. The success of Layang-layang KB Village can be seen from several awards received at the local and national level.

Layang-layang KB Village community already fell social benefits. In this case, adolescent associations in this village must have activities especially teenagers. They are involved in positive activities such as tutoring, English lesson, reading, etc. The focus of the Layang-layang KB village activities at the moment is preventing dropouts and providing employment for school dropouts.

\section{$B$. The influence factors of the $K B$ village program in the Layang-layang $K B$ village}

Many variables are influencing the success of policies. The implementation of a program is influenced by the involvement and efforts of policymakers to be able to influence policy implementers. They are willing to provide services and manage target groups. For simple policies, implementation involves only one body that functions as an implementor, in contrast to macro policies, implementation efforts will involve various institutions, such as district bureaucracy, sub-districts and village governments [9].

Based on the results of the study note that there are several factors that influence the success of the village family program in Layang-layang KB village in Palembang, including supporting factors and inhibiting factors. Supporting factors for the success of this program include community understanding, active participation of cadres, continuous socialization, the role of community leaders and stakeholder support be a benefit for this village. In addition, there are several inhibiting factors, including limited funding, lack of coordination across sectors, community involvement is not yet comprehensive, and lack of guidance from various fields. Explanation about the factors that influence the success of the program and how to solve the inhibiting factor will be discussed in part of the discussion.

\section{DISCUSSION}

Learning from the success of the Layang-layang KB village is known as a number of factors driving their success in making the layang-layang $\mathrm{KB}$ village as a village pilot project. These factors can be an advantage for the village in realizing the goals of achieving a comfortable environment and a prosperous community.

The growth and development of community participation are determined by people's perceptions of the level of importance and information conveyed to them. Responses arising from an understanding of the importance of community participation in a program will vary greatly depending on their level of understanding. The clear information obtained a higher understanding of being able to participate in this program. Program understanding will 
create good cadres, who understand their duties and functions, form working groups in accordance with the cadre's ability to create a solid team. Layang-Layang KB Village has a very rapid development because the cadres and management are very active compared to other $\mathrm{KB}$ villages. Cadre and management are policy implementing agents. The acceptance and rejection behavior of implementing agents greatly affect the success and failure of policy implementation [10].

In addition to the activeness of cadres, the socialization factor is also a critical success factor because a comprehensive socialization program can reach all parties and interests. Especially socialization to the community. They know about the program and its benefits. The socialization process can succeed or fail. Due to the knowledge and methods used by the socialization agent to the people receiving the information. People's perceptions are also influenced by social and cultural values. Therefore, it is important that the socialization agent approaches the community through cultural means. There is no misunderstanding in the delivery of information. The success socialization of the KB Village program was driven by an agent who was able to motivate and invite his citizens to take part in family planning activities.

In Layang-layang $\mathrm{KB}$ village, the prime mover was a neighborhood head. He was able to invite his citizens to advance their village to be better than before. He also had initiatives and ideas in terms of finding funding for their activities. What was unique in the Layang-layang KB village is, they did not want to receive financial aid in the form of money, but received assistance in the form of items to facilitate the activities of the Layang-layang $\mathrm{KB}$ village.

The last supporting factor was to influence the success of this program is stakeholders. Stakeholders have legal authority in making decisions for a program. Support from the city government of Palembang, the private sector and academics as a stakeholder are needed to assist in terms of assistance, provision of facilities and funding in every activity carried out by the KB village. Support from stakeholders from this case already exists but not yet optimal.

On the other hand, there are also inhibiting factors of the program successfully. First, limited funding. Funding is important to reach the goal. Without funding, a program might work but the course of the program will not be effective and may also not reach the goal perfectly.

Second, a lack of coordination across the sector. Good coordination makes work completed quickly because coordination allows the work to be divided perfectly. Lack of coordination can make work failed and inefficient, this is due to the loss of the role of one or more parties who should be able to support the program. The lack of coordination between agencies in the $\mathrm{KB}$ village program makes the problems not easy to the Office population control and family planning.

The next factor was a community involvement is not yet comprehensive, making people want to be involved in a program is not easy if the community does not know what benefits they will have when participating in a program. For this reason, communication skill is needed from policy implementing agencies to communicate the benefits of the programs has implemented.

The last factor is the lack of guidance from various fields, the role of institutions in developing is needed because universities are expected to be able to study the problems faced with a scientific approach and able to solve the problems. The role of universities as agents of change can also involve students in community service activities. with the broad scope of knowledge from various fields in universities will be very helpful in achieving the program. Universities that gather academics and experts have expertise in various fields of science should be able to develop centers of excellence that are suitable for development needs.

\section{CONCLUSION}

The family planning village program in the Layanglayang KB village has been quite successful involving community participation, this can be seen from the community participation in every activity that is held. The type of participation shows the impact of this program on the economy and welfare of the community in the layanglayang KB village. Supporting factors for the success of this program can be a benefit for this village. Otherwise, there are several inhibiting factors, will be the problem and it must be found in a solution. For recommendations, community independence and assistance from various parties are still needed to solve the problem, so the goals of the program can be realized.

\section{ACKNOWLEDGMENTS}

This research has found the type of community participation and describes the determinants of success in the Layang-layang $\mathrm{KB}$ village. The authors would like to thanks the Layang-layang KB Village Community and cadre in Palembang, who had agreed to be the informant in this research, especially to Mr. Usman Aris the coordinator Layang-layang KB Village for cooperation and assistance in providing data and also given thanks to the population control of family planning office to providing information about the $\mathrm{KB}$ village program in Palembang City and offering cooperation, so that the university could provide assistance to other $\mathrm{KB}$ villages, to imitate and learn from the success of the Layang-layang KB village.

\section{REFERENCES}

[1] Alisjahbana, Komunikasi Lingkungan. Bandung: Simbiosa Rektama, 2019.

[2] D. R. Rahadi, "Model Pengembangan Kampung sebagai Desa Inovatif (Studi Kasus Kota Palembang)," FIRM J. Manag. Stud., vol. 1, no. 2, 2016.

[3] T. Mardikanto and S. Poerwoko, Pemberdayaan Masyarakat dalam Perspektif kebijakan publik. Bandung: Alfabeta, 2017.

[4] R. A. Isbandi, Perencanaan Partisipatoris Berbasis Aset Komunitas: dari Pemikiran Menuju Penerapan. Depok: FISIP UI Press, 2007

[5] H. A. R. Tilaar and R. Nugroho, Kebijakan Pendidikan: Pengantar untuk Memahami Kebijakan Pendidikan dan Kebijakan Pendidikan sebagai Kebijakan Publik. Yogyakarta: Pustaka Pelajar, 2009.

[6] S. . Arnstein, "A ladder of citizen participation," J. Am. Inst. Plann., vol. 35, no. 4, pp. 216-224, 1969.

[7] Sugiyono, Metode Penelitian Pendidikan Pendekatan Kuantitatif, Kualitatif, dan R\&D. Bandung: Alfabeta, 2014.

[8] M. B. Miles and M. A. Huberman, Qualitative data analysis. Jakarta: Universitas Indonesia Press, 1992.

[9] A. Subarsono, Analisis Kebijakan Publik (konsep. teori dan aplikasi). Yogyakarta: Pustaka Pelajar, 2016

[10] L. Agustino, Dasar-dasar Kebijakan Publik. Bandung: Alfabeta, 2006. 